\title{
New Approach to Municipal Grey Water Footprint Estimation: A Case Study for Aegean Region Cities in Turkey
}

\author{
Hülya Boyacıoğlu \\ Department of Environmental Engineering, Faculty of Engineering, Tinaztepe Campus, Dokuz Eylül University, Turkey
}

Copyright $(2018$ by authors, all rights reserved. Authors agree that this article remains permanently open access under the terms of the Creative Commons Attribution License 4.0 International License

\begin{abstract}
This study aimed to develop an approach to investigate grey water footprint-GWF of municipalities in the Aegean Region in Turkey. In this scope 8 out of 81 cities were analyzed in terms of their waste water production (volume), waste water treatment (type of treatment, waste water receiving media etc.) in the country. Data was handled, within the series of waste water official surveys at a municipal level published annually/ bi-annually by the National Institute of Statistics (TUIK) since 2001. "Total Nitrogen TN" has been selected as a reference variable for GWF calculations. The required additional data/information for the calculations was natural/background nitrogen concentrations, maximum allowable nitrogen concentrations for water bodies. Grey water footprint was calculated for each single city and then spatial differences were determined. Study results revealed that GWF was changeable from one city to another (450-1150 $\mathrm{m}^{3} /$ ca.yr). Higher GWF (treated) amount compared to the GWF (un-treated) in some regions was explained by higher volume of treated wastewater. Observation of relatively high values for GWF (treated) in some places was due to type of water treatment processes. Availability of $\mathrm{N}$ removal process at treatment plants was major impact on low GWF value. It can be concluded that GWF could be indicator to investigate effectiveness of wastewater management strategies, and determine its environmental effects.
\end{abstract}

Keywords GWF Grey Water Footprint, Natural Background Concentration, Maximum Allowable Concentration

\section{Introduction}

The water footprint is an indicator of human appropriation of freshwater resources. It measures both the direct and indirect "water use" of consumers and producers. The term "water use" refers to two different components: consumptive water use (of rainwater-the green water footprint and of surface and groundwater- the blue water footprint) and degenerative water use (the Grey water footprint).

The Grey water footprint (GWF) is an indicator of the water volume needed to assimilate a pollutant load that reaches a water body. As an indicator of water resources appropriation through pollution, it provides a tool to help assess the sustainable, efficient and equitable use of water resources The advantage of expressing water pollution in terms of the water volume required for assimilating the pollutants, rather than in terms of concentrations of contaminants, is that this brings water pollution into the same unit as consumptive use [1, 2, 3].

Recent studies mostly focused on the industrial and agricultural production $[4,5,6]$. This study will be one of the pioneer research focusing on municipal grey water footprint.

\section{Study Area}

The study area covers nearly one-eighth of the Anatolian Peninsula (of Turkey) and is located approximately within the latitudes $368000-408000 \mathrm{~N}$ and the longitudes 268000 $-318000 \mathrm{E}$ (Fig. 1). The region has a Mediterranean climate with annual mean precipitations ranging from 450 to $1200 \mathrm{~mm} / \mathrm{yr}$ [7]. Population served by sewage system and annual discharged wastewater per capita is presented in Table 1.

\section{Study Method}

In the study "Total Nitrogen TN" has been selected as a reference variable for GWF calculations and anthropogenic nitrogen $(\mathrm{N})$ loads to freshwater was estimated for each 
city in the region. Data was handled, within the series of waste water official surveys at a municipal level published annually/bi-annually by the National Institute of Statistics (TUIK) since 2001 [5]. The estimated pollutant load generated by the municipalities was based on information for the year 2014 .

Table 1. Population served by sewage system and discharged water as of 2014 [8]

\begin{tabular}{|c|c|c|}
\hline City & $\begin{array}{c}\text { Population } \\
\text { (as of 2014) }\end{array}$ & $\begin{array}{c}\text { Water discharges } \\
\left(\mathrm{dm}^{3} / \text { ca.day }\right)\end{array}$ \\
\hline İzmir & 3825157 & 214 \\
\hline Manisa & 1258473 & 122 \\
\hline Aydın & 937781 & 181 \\
\hline Denizli & 782960 & 198 \\
\hline Muğla & 626156 & 361 \\
\hline Afyonkarahisar & 497721 & 154 \\
\hline Kütahya & 424493 & 192 \\
\hline Uşak & 233763 & 148 \\
\hline
\end{tabular}

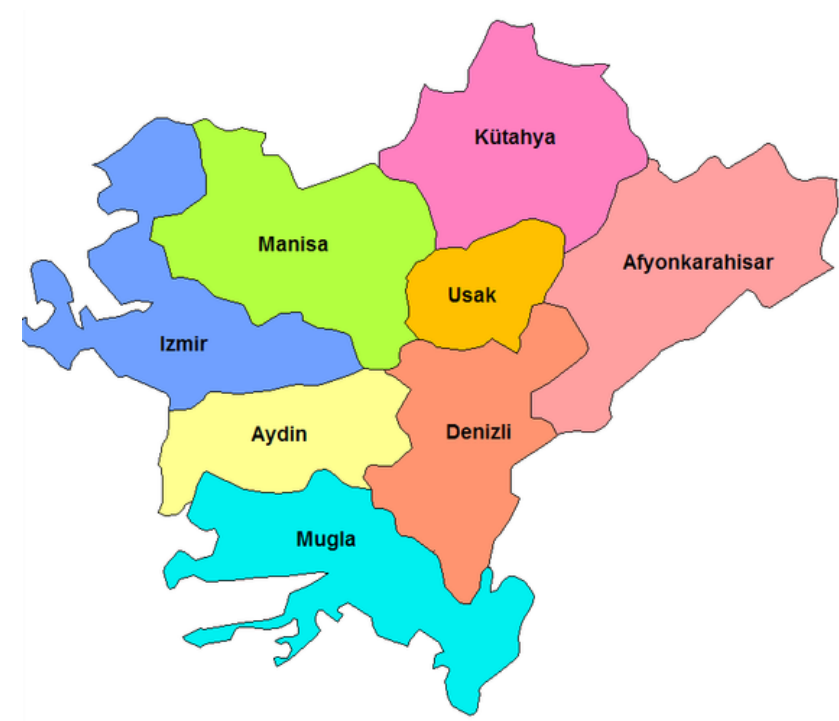

Figure 1. Aegean Region Cities

Grey Water Footprint: The Grey water footprint (GWF, $\mathrm{m}^{3} / \mathrm{ca}$.yr) is calculated by dividing the $\mathrm{N}$ load (Load, $\mathrm{kg} / \mathrm{ca} . \mathrm{yr}$ ) by the difference between the ambient water quality standard for $\mathrm{N}$ (the maximum acceptable concentration $\mathrm{C}_{\max }, \mathrm{mg} / \mathrm{L}$ ) and the natural concentration of $\mathrm{N}$ in the receiving water body $\left(\mathrm{C}_{\mathrm{nat}}\right.$, in $\left.\mathrm{mg} / \mathrm{L}\right)$ :

$$
G W F=\frac{\text { Load }}{\left(C_{\max }-C_{\text {nat }}\right)}
$$

The natural concentration in a receiving water body $\left(\mathrm{C}_{\text {nat }}\right)$ is the concentration in the water body that would occur if there were no human disturbances in the catchment. For human-made chemical substances that naturally do not occur in water, $\mathrm{C}_{n a t}$ is zero. When natural concentrations are not known precisely but are estimated to be low, for simplicity one may assume $C_{\text {nat }}$ is also zero. However, when $\mathrm{C}_{\text {nat }}$ is actually not equal to zero, this results in an underestimated GWF, because the assimilation capacity for the chemical substance would be overestimated [2]. For the natural background concentrations, local data are suggested to be used. If local data are not available and time and budget do not allow determining the natural background concentrations, the values in the literature could be used.

Regarding the maximum allowable concentrations in ambient water bodies, "The Water Footprint Assessment Manual" suggests to use local ambient water quality standards. However, for comparative studies, in which GWF estimates for different locations are to be compared, it is recommended to take the same standards throughout the study. Regarding the maximum allowable concentrations in ambient water bodies, these guidelines suggest to select the strictest standard as used in the European Union, the United States or Canada. These standards are up to date and scientifically most reliable [2].

In the literature there are different values for maximum allowable and natural concentrations. For this study, the maximum acceptable value provided by the GWF guidelines, $2.96 \mathrm{mg} \mathrm{N} / \mathrm{L}$, which is based on the guideline for the protection of aquatic life as proposed by the Canadian Council of Ministers of the Environment was used [9]. The same guidelines from the Water Footprint Network suggest a natural concentration value for total $\mathrm{N}$ of $0.38 \mathrm{mg} \mathrm{N} / \mathrm{L}$, which is close to the average natural concentration of $\mathrm{N}$ in rivers of $0.375 \mathrm{mg} \mathrm{N} / \mathrm{L}$ reported by Meybeck [10] (see Table 2 and 3).

Table 2. Maximum allowable concentration of nutrients [after 2]

\begin{tabular}{|c|c|}
\hline Nutrients & Maximum allowable concentration $\mu \mathrm{g} / \mathrm{L}$ \\
\hline Ammonia $-\mathrm{NH}_{3}$ & $19 \mathrm{NH}_{3}$ \\
\hline Nitrate $\mathrm{NO}_{3}$ & $13000 \mathrm{NO}_{3}$ \\
\hline Nitrite $\mathrm{NO}_{2}$ & $60 \mathrm{NO}_{2}-\mathrm{N}$ \\
\hline
\end{tabular}

Table 3. Natural/background concentrations nutrients [after 2]

\begin{tabular}{|c|c|}
\hline Nutrients & Natural/background concentrations $(\mathrm{mg} / \mathrm{L})$ \\
\hline Ammonium $\mathrm{N}-\mathrm{NH}_{4}$ & 0.015 \\
\hline Nitrate $\mathrm{N}_{4} \mathrm{NO}_{3}$ & 0.1 \\
\hline $\mathrm{N}$ organic & 0.26 \\
\hline
\end{tabular}

"Load $\left(\mathrm{m}^{3} / \mathrm{ca}\right.$.yr)" was calculated by adding together the treated pollutant load and untreated pollutant load. For this calculation following classes were created for each city.

- Untreated wastewater amount $\left(\mathrm{m}^{3} / \mathrm{ca}\right.$. yr. $)$

- Treated wastewater amount $\left(\mathrm{m}^{3} / \mathrm{ca}\right.$.yr). (classified according to the following treatment type)

- Untreated wastewater

- Secondary treatment

- Physical treatment

- $\quad$ Advanced treatment (nutrient removal) 
Based on the treatment level, concentration of $\mathrm{C}$ was estimated (see Table 4) and this value was multiplied by amount of wastewater to determine load ( $\mathrm{kg} / \mathrm{ca} . \mathrm{yr})$.

$$
\mathrm{L}=\mathrm{C} \times \mathrm{Q}
$$

Table 4. Typical effluent quality for various levels of treatment [after 11 and 12]

\begin{tabular}{|c|c|}
\hline Treatment process & Total N $(\mathrm{mg} / \mathrm{L})$ \\
\hline Untreated wastewater & 60 \\
\hline Secondary treatment & 30 \\
\hline Physical treatment & 40 \\
\hline Advanced treatment (nutrient removal) & 15 \\
\hline
\end{tabular}

\section{Results and discussion}

GWF ( $\mathrm{m}^{3} / \mathrm{ca}$.yr), population served by sewage system and waste water discharges $\left(\mathrm{m}^{3} / \mathrm{ca}\right.$.yr) values for each cities are presented in Table 5. Spatial distribution of water discharges and GWF is depicted on the maps that were created using Arc Map 10.3.1 (see Fig 2 through 5).

From Table 4, it is concluded that not only the wastewater amount but also treatment level has impact on GWF. Thus GWF from discharged waste water, treated wastewater and untreated wastewater for each city was calculated and results are shown in Fig. 3-5.

The outcomes of the study revealed that:

- Annual waste water discharges per capita showed difference mainly between $40-80 \mathrm{~m}^{3} / \mathrm{ca}$.yr except Muğla. This value was $130 \mathrm{~m}^{3} / \mathrm{ca} . y r$ in this city and high touristic activities is considered as a reason for this extreme amount.

- GWF was also changeable from one city to another $\left(450-1150 \mathrm{~m}^{3} / \mathrm{ca}\right.$.yr). Lowest value was observed for "Izmir" where $\% 100$ of the municipal water is treated.

- Higher GWF (treated) compared to the GWF (un-treated) in some regions was explained by higher treatment rate of wastewater

- Observation of relatively high values for GWF (treated) in some regions was explained by type of water treatment processes. Availability of $\mathrm{N}$ removal process at treatment plants was also major impact on low GWF value.

Table 5. GWF of cities $\left(\mathrm{m}^{3} / \mathrm{ca} . \mathrm{yr}\right)$

\begin{tabular}{|c|c|c|c|}
\hline City & Population served by sewage system (as of 2014) & Water discharges ( $\left.\mathrm{m}^{3} / \mathrm{ca} . \mathrm{yr}\right)$ & $\begin{array}{c}\text { GWF } \\
\left(\mathrm{m}^{3} / \text { ca.yr }\right)\end{array}$ \\
\hline İzmir & 3825157 & 78.1 & 451 \\
\hline Manisa & 1258473 & 44.5 & 1145 \\
\hline Aydın & 937781 & 66.1 & 774 \\
\hline Denizli & 782960 & 72.3 & 971 \\
\hline Muğla & 626156 & 131.8 & 1688 \\
\hline Afyonkarahisar & 497721 & 56.2 & 702 \\
\hline Kütahya & 424493 & 70.1 & 854 \\
\hline Uşak & 233763 & 54.0 & 492 \\
\hline
\end{tabular}

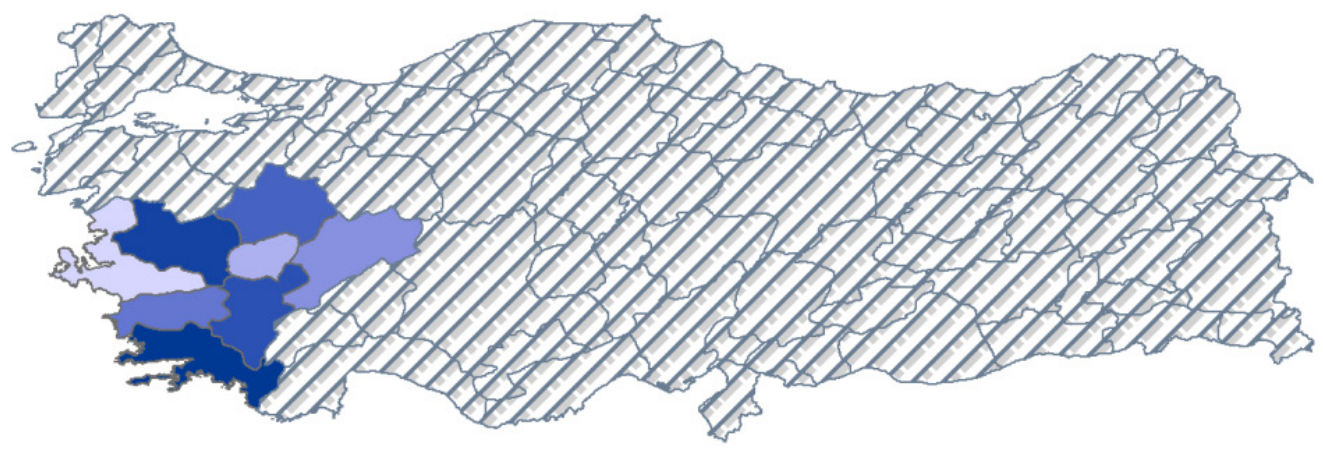

GWF (m3/ca.yr)
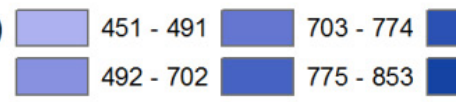

854 - 970

$1145-1687$

Figure 2. Grey water footprint of study region 

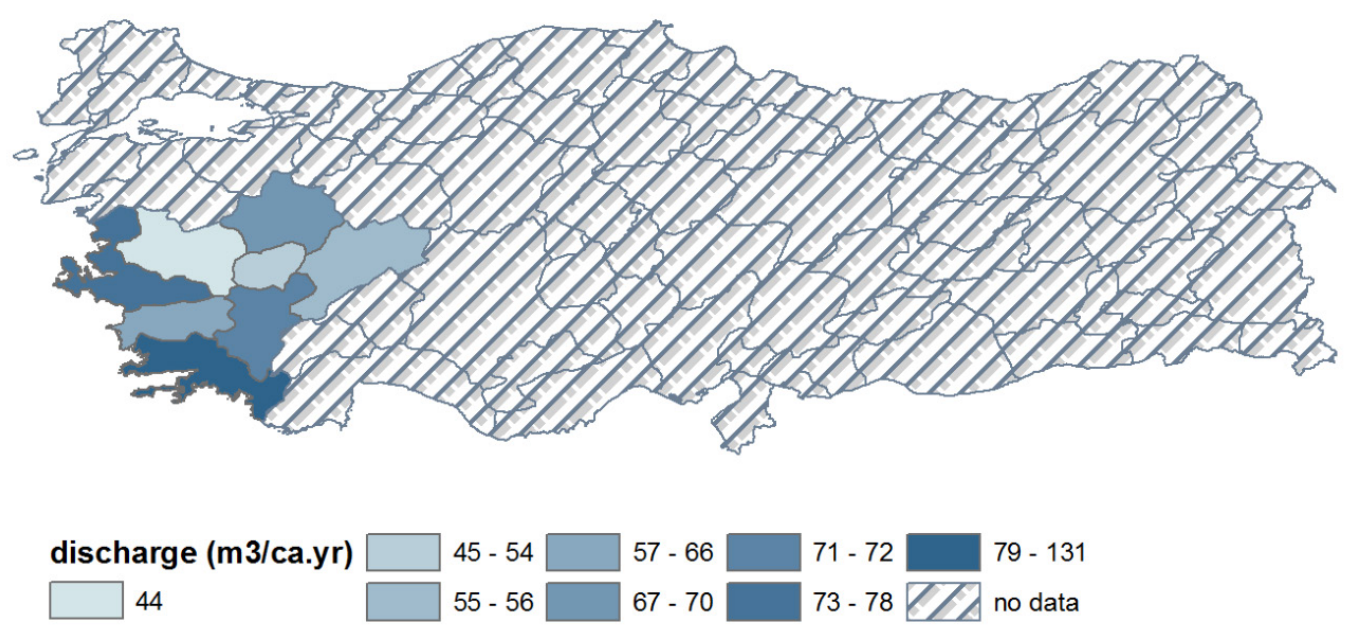

Figure 3. Amount of discharged municipal waste water
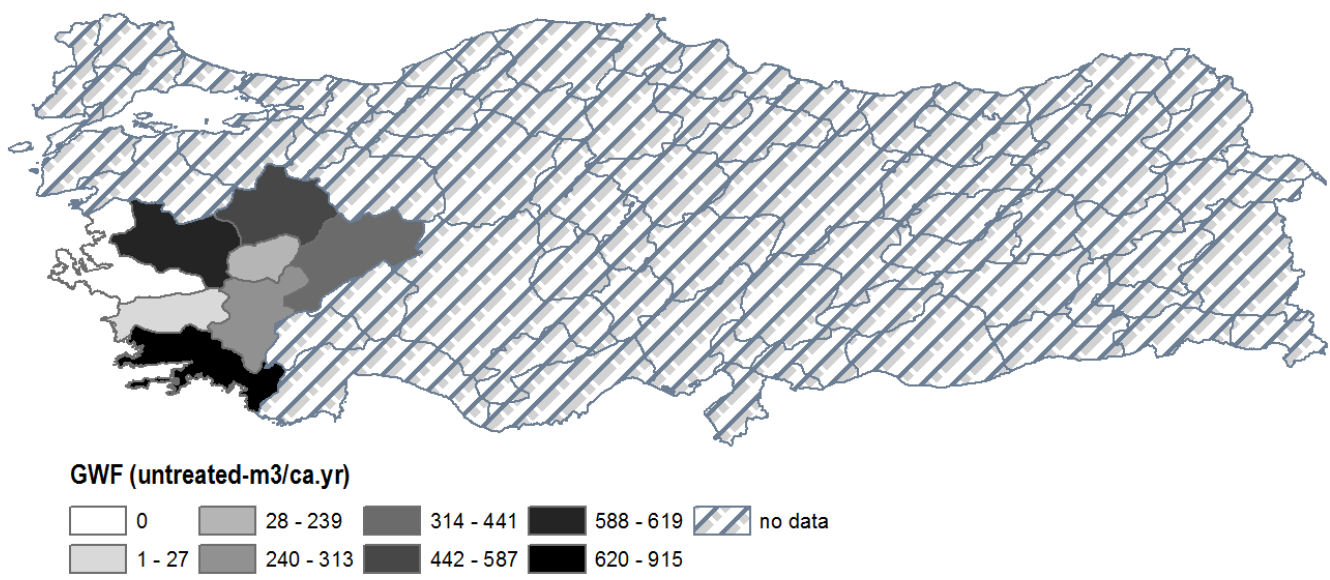

Figure 4. GWF from discharged wastewater (un-treated)

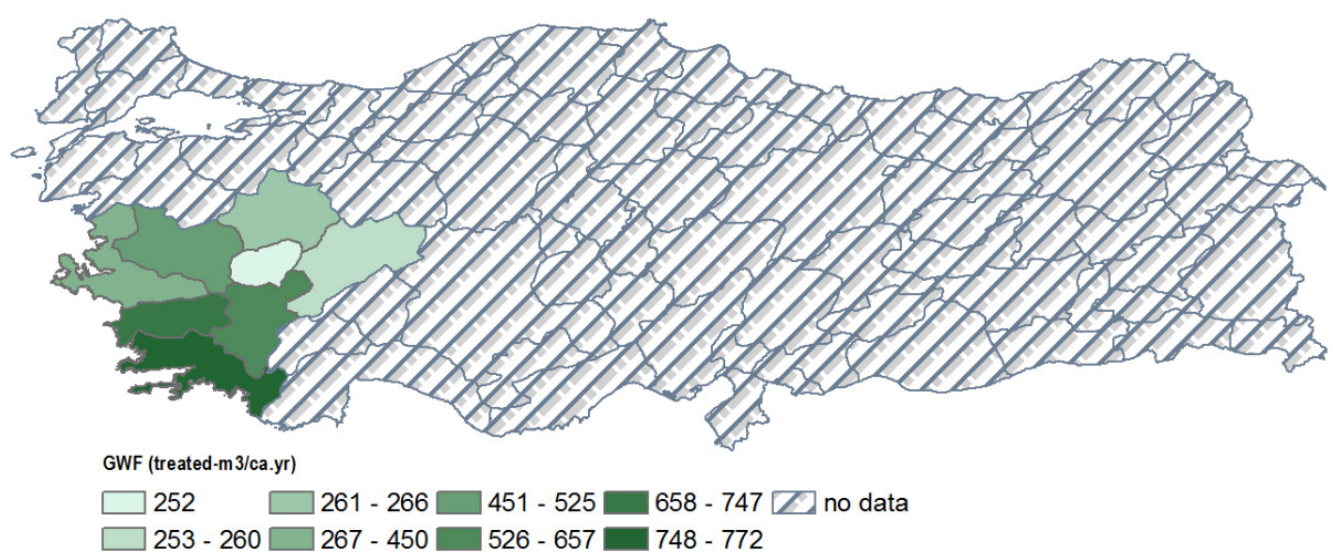

Figure 5. GWF from discharged wastewater (treated) 


\section{Conclusions}

This study aimed to develop an approach to investigate grey water footprint of municipalities in the Aegean Region in Turkey. In this scope 8 out of 81 cities were analyzed in terms of their waste water production (volume), waste water treatment (type of treatment, waste water receiving media etc.) in the country. "Total Nitrogen TN" has been selected as a reference variable for GWF calculations. The required additional data/information for the calculations was natural/background nitrogen concentrations, maximum allowable nitrogen concentrations for water bodies. Grey water footprint was calculated for each single city and then spatial differences were determined. Based on the results it was concluded that GWF was changeable from one city to another and with the range of $450-1150 \mathrm{~m}^{3} / \mathrm{ca}$.yr. Higher GWF for treated compared to the un-treated wastewaters in some regions was explained by higher treated amount of wastewater (in volume). Observation of relatively high values for GWF (treated) in some places was due to type of water treatment processes. Availability of $\mathrm{N}$ removal process at treatment plants was major impact on low GWF value. In summary GWF could be indicator to investigate effectiveness of wastewater management strategies, and determine its environmental effects.

\section{REFERENCES}

[1] Mekonnen M.M and Hoekstra A.Y (2015) Global Grey Water Footprint and Water Pollution Levels Related to Anthropogenic Nitrogen Loads to Fresh Water. Environ. Sci. Technol. 2015, 49, 12860-12868

[2] Franke, N.A., Boyacioglu, H. and Hoekstra, A.Y. (2013) Grey water footprint accounting: Tier 1 supporting guidelines, Value of Water Research Report Series No. 65, UNESCO-IHE, Delft, the Netherlands.

[3] Vieira B and Junior W.S. (2015) Contributions Toward A Municipal Approach To Water Footprint: Case Study In A Brazilian Coastal City Ambient. soc.vol.18 no.3 São Paulo July/Sept.2015

[4] Gerbens-Leenes P.W., Hoekstra A.Y. and Bosman R (2018). The blue and grey water footprint of construction materials: Steel, cement and glass. Water Resources and Industry Volume 19, pp. 1-12

[5] Isabel Martínez-Alcalá I.M, Martínez F.P and López C.F (2018) Pharmaceutical grey water footprint: Accounting, influence of wastewater treatment plants and implications of the reuse Water Research.

https://doi.org/10.1016/j.watres.2018.02.033

[6] Vergé X, Vander Zaag A, Smith W, Grant B and Gordon R (2017) The consideration of time step in calculating grey water footprints of agricultural cropping systems. Ecological Indicators, Volume 78, Pages 31-36

[7] Așikoğlu Ö.L, Ciftlik D (2015) Recent Rainfall Trends in the Aegean Region of Turkey Journal of Hydrometeorology. DOI: 10.1175/JHM-D-15-0001.1

[8] Turkish Statistical Institute (2017) Waste Water statistics of municipalities. Accessed on March 152017 from https://biruni.tuik.gov.tr/medas/?kn=120\&locale $=$ tr

[9] CCME (2013) Canadian Water Quality Guidelines for the Protection of Aquatic Life; Canadian Council of Ministers of the Environment: Winnipeg, Canada, 2013.

[10] Meybeck, M. (1982) Carbon, nitrogen and phosphorus transport by world rives. Am. J. Sci. 282, 401-450

[11] MoEF (2010). Turkish Ministry of Environment and Forest. Technical procedures of waste water treatment plants. Official Gazette Dated 20 March 2010 Numbered 27527

[12] Metcalf and Eddy Inc. (1991) Wastewater Engineering: Treatment, Disposal and Reuse. Third Edition. McGraw-Hill Publishing Co., New York. 